\title{
Ataxia-Pancytopenia Syndrome due to a de Novo SAMD9L Mutation
}

Josh King-Robson, BMBS BSc (Hons), MRCP, Joseph Marshall, MBBS MSc, Frances Smith, BSc (Hons), DipRCPath, Leanne Willoughby, BSc (Hons), Sahar Mansour, BMBS, FRCP, and Laszlo Sztriha, MD PhD FRCP

Neurol Genet 2021;7:e580. doi:10.1212/NXG.0000000000000580
Correspondence

Dr. King-Robson

j.king-robson@nhs.net

\section{Introduction}

Ataxia pancytopenia syndrome (ATXPC; MIM 159550) is an autosomal dominant cerebellar ataxia associated with hematological abnormalities including pancytopenia and a predisposition to haematological malignancy (myelodysplasia and acute myeloid leukaemia). To date, 4 families have been described harboring gain of function SAMD9L mutations which underlie ATXPC. ${ }^{1-4}$ Here we describe a de novo SAMD9L pathogenic variant in a patient with myelodysplasia, presenting with a subacute cerebellar syndrome.

\section{Case Presentation}

A 28-year-old woman presented to a tertiary neurologic center with a 6-week history of headache, diplopia, and ataxia, which started after cellulitis at the site of a pneumococcal and influenza vaccination. On examination, there was mild gait ataxia, slow saccades, diplopia in all directions of gaze without extraocular nerve palsy, and prominent downbeating nystagmus. Her medical history confirmed myelodysplastic syndrome, diagnosed 12 years previously. There was no relevant family history.

Initial investigations, including CSF and a broad panel of autoimmune and metabolic investigations, were unremarkable. MRI of the brain demonstrated confluent, symmetrical periventricular and deep white matter T2 hyperintensity, extending to involve the striatum, with periventricular cystic foci surrounding the lateral ventricles (figure 1A). There was marked cerebellar atrophy with both vermian and hemispheric volume loss (figure 1B). Whole body $\left[{ }^{18} \mathrm{~F}\right]$ FDG-PET demonstrated diffuse cerebellar hypometabolism (figure 1C) and excluded active malignancy. Electroencephalography revealed occasional sharpened theta waves over the frontal region against a posterior background activity in the alpha range. Ophthalmology examination demonstrated no ocular abnormality with normal optical coherence tomography.

Whole genome sequencing of the proband and both parents revealed a heterozygous missense pathogenic variant of the SAMD9L gene (NM_152703.5:c.2956C >T, p.(Arg986Cys)) in the proband only and confirmed parentage. Sanger sequencing was carried out in the proband and both parents, confirming that the variant had arisen de novo in the patient (figure 1D). This variant is not seen in the gnom $\mathrm{AD}$ population database but was previously described by Tesi et al. ${ }^{1}$ in a 3-generation family with ATXPC (F1).

Array comparative genomic hybridization (CGH) demonstrated a mosaic interstitial deletion on the long arm of chromosome 7 within the hematopoietic cell line, from bands q11.23 to q33

From the Neurology Department (J.K.-R.), King's College Hospital; Neurology Department (J.M.), King's College Hospital; Molecular Pathology (F.S.), Viapath at Kings College Hospital; South East Genomic Laboratory Hub (L.W.), Guy's \& St Thomas' NHS Foundation Trust; SW Thames Regional Genetics Service (S.M.), St George's University of London; and Neurology Department (L.S.), King's College Hospital, London, United Kingdom.

Go to Neurology.org/NG for full disclosures. Funding information is provided at the end of the article. 


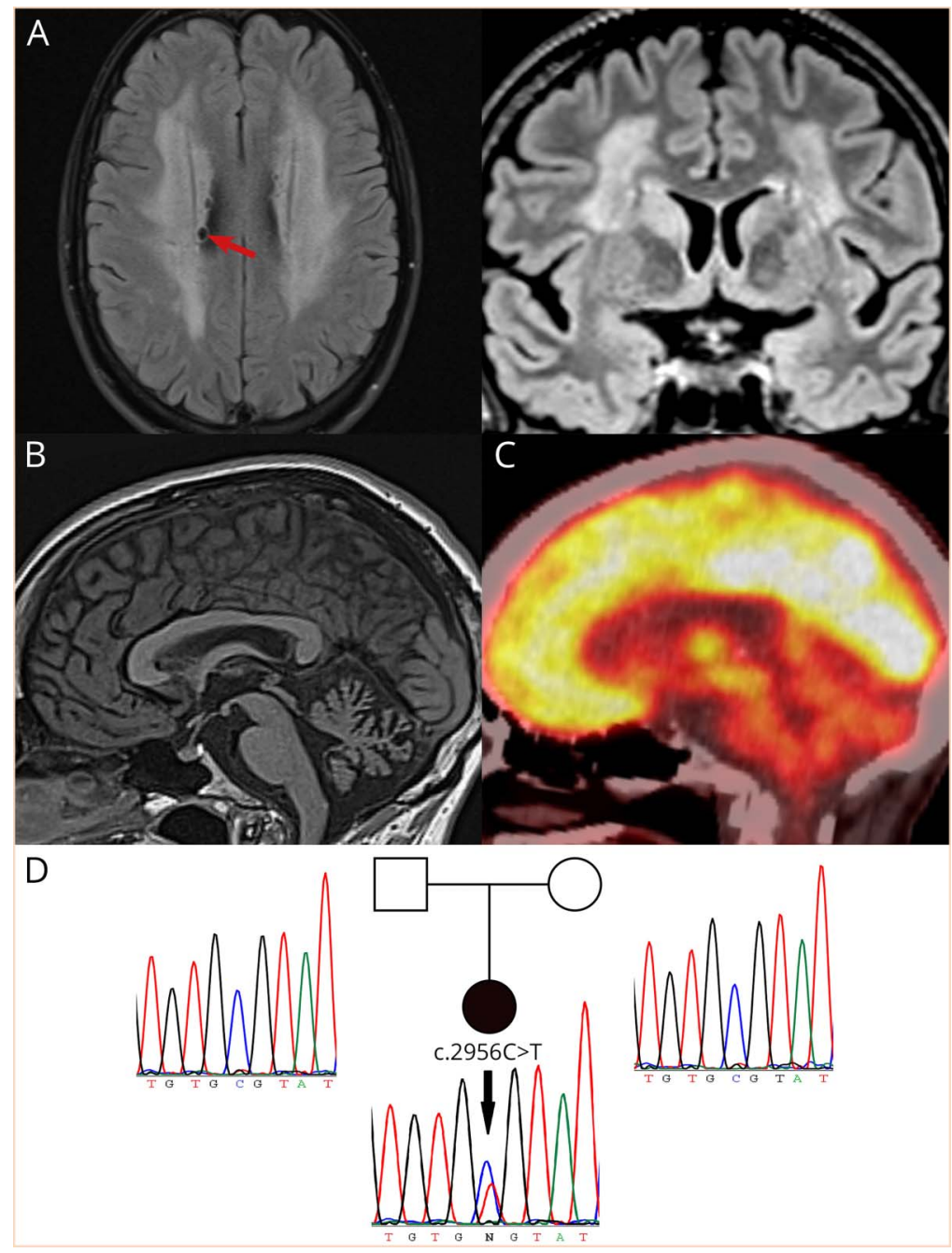

Brain MRI changes included periventricular T2 white matter hyperintensities with cystic change (arrow) (A), alongside marked cerebellar atrophy with both vermian and hemispheric volume loss (B). [ ${ }^{18}$ F]FDG-PET revealed diffuse cerebellar hypometabolism (C). Whole genome sequencing demonstrated a de novo gain of function (GOF) mutation in the SAMD9L gene on chromosome 7, confirmed by sanger sequencing of the proband and asymptomatic parents (D).

(arr[GRCh37] 7q11.23q33 (76030573_137802149)x1[0.5], figure e-1, links.lww.com/NXG/A404). This deletion encompasses the SAMD9L gene and was present in $50 \%$ of cells.

\section{Discussion}

ATXPC is caused by gain of function pathogenic variants of the SAMD9L tumor suppressor gene. The disorder is extremely rare; of those 35 patients with SAMD9L mutations reported worldwide by the Human Gene Mutation Database, 6 have ATXPC, whereas the remainder are characterized by myelodysplastic syndrome or bone marrow failure. ${ }^{2}$ The literature reports 4 families in addition to the case reported here. ${ }^{1,3,4}$

Overactivity of $S A M D 9 L$ results in the cerebellar atrophy and pancytopenia that engender the clinical presentation. Brain MRI demonstrates cerebellar volume loss accompanied frequently by periventricular white matter $\mathrm{T} 2$ hyperintensities. ${ }^{1,4,5}$ Histopathologic studies have shown diffuse loss of Purkinje cells and-to a lesser extent-cerebellar granule cells, the mechanism for which remains unclear. ${ }^{4}$

Germline SAMD9L gain of function pathogenic variants cause bone marrow suppression with pancytopenia. Acquired monosomy 7 or partial deletion of chromosome 7 may arise to circumvent the repression of hematopoiesis. These can act as a "rescue mechanism" that inactivates the gain of function mutation by nonrandom loss of the mutated SAMD9L allele (figure e-2, links.lww.com/NXG/A405). ${ }^{6}$ Consequently, spontaneous recovery from the pancytopenia may occur ("hemopoietic reversion"). However, partial or total deletions of chromosome 7 may lead to clonal expansion of a cell line (myelodysplastic syndrome), as occurred in our patient, and predispose to acute myeloid leukaemia. ${ }^{7}$

The age at onset of neurologic symptoms in familial cases varies widely, ranging from 4 to 62 years, followed by invariably slow progression. ${ }^{4,5}$ The neurologic presentation is often preceded by the hematological manifestations, as in the patient reported here. 
Although the exact triggers for this patient's subacute presentation are not clear, possibilities include decompensation of the already compromised cerebellar system because of intercurrent infection or parainfectious phenomenon after recent immunization.

The mainstay of the management for SAMD9L-associated hematological abnormalities includes monitoring for the development of hematological malignancy and allogenic stem cell transplantation. Stem cell transplantation seems to have no effect on neurologic outcomes, and the management of neurologic abnormalities of ATXPC remains supportive. ${ }^{1}$

With input from the wider multidisciplinary team, including neuro-ophthalmology, hematology, clinical genetics, and physiotherapy, the patient reported here continues to be independent and an avid cyclist. The patient initially found improvement in her diplopia with the use of occlusive lenses; however, these are no longer required, and the only remaining abnormality on examination is mild nystagmus.

Shortly after diagnosis, the patient became pregnant. Prenatal testing, by chorionic villus sampling at 12 weeks, confirmed the baby to be negative for the familial variant in SAMD9L (unaffected). The patient remained well throughout an uneventful pregnancy.

This case of de novo SAMD9L pathogenic variant in ATXPC highlights the value of whole genome sequencing, leading to an accurate diagnosis, appropriate surveillance and treatment, and opening the option of prenatal diagnosis.

\section{Acknowledgment}

This research was made possible through access to the data and findings generated by the 100,000 Genomes Project. The 100,000 Genomes Project is managed by Genomics England Limited (a wholly owned company of the Department of Health and Social Care). The 100,000 Genomes Project is funded by the National Institute for Health Research and NHS England. The Wellcome Trust, Cancer Research UK, and the Medical Research Council have also funded research infrastructure. The 100,000 Genomes Project uses data provided by patients and collected by the National Health Service as part of their care and support. Josh King-Robson's research is funded by the National Institute for Health Research (NIHR). The views expressed are those of the author(s) and not necessarily those of the NIHR or the Department of Health and Social Care.

\section{Study Funding}

The authors report no targeted funding.

\section{Disclosure}

J. King-Robson, J. Marshall, F. Smith, L. Willoughby, S. Mansour, and L. Sztriha report no disclosures relevant to the manuscript. Full disclosure form information provided by the authors is available with the full text of this article at Neurology.org/NG.

\section{Publication History}

Received by Neurology: Genetics October 20, 2020. Accepted in final form February 16, 2021.

Appendix Authors

\begin{tabular}{|c|c|c|}
\hline Name & Location & Contribution \\
\hline $\begin{array}{l}\text { Josh King- } \\
\text { Robson, BMBS } \\
\text { BSc (Hons) } \\
\text { MRCP }\end{array}$ & $\begin{array}{l}\text { King's College Hospital, } \\
\text { London, United Kingdom }\end{array}$ & $\begin{array}{l}\text { Drafted the manuscript } \\
\text { and illustrative figure }\end{array}$ \\
\hline $\begin{array}{l}\text { Joseph } \\
\text { Marshall, } \\
\text { MBBS MSc }\end{array}$ & $\begin{array}{l}\text { King's College Hospital, } \\
\text { London, United Kingdom }\end{array}$ & $\begin{array}{l}\text { Revision of the } \\
\text { manuscript }\end{array}$ \\
\hline $\begin{array}{l}\text { Leanne } \\
\text { Willoughby, } \\
\text { BSc (Hons) }\end{array}$ & $\begin{array}{l}\text { South East Genomic } \\
\text { Laboratory Hub, Guy's \& } \\
\text { St Thomas' NHS } \\
\text { Foundation Trust }\end{array}$ & $\begin{array}{l}\text { Interpretation and } \\
\text { reporting of array } \\
\text { comparative genomic } \\
\text { hybridization results } \\
\text { and preparation of the } \\
\text { figure }\end{array}$ \\
\hline $\begin{array}{l}\text { Frances } \\
\text { Smith, BSc } \\
\text { (Hons) } \\
\text { DipRCPath }\end{array}$ & $\begin{array}{l}\text { Viapath at Kings College } \\
\text { Hospital, London, United } \\
\text { Kingdom }\end{array}$ & $\begin{array}{l}\text { Performed and } \\
\text { interpreted Sanger } \\
\text { sequencing and prepared } \\
\text { sequencing images }\end{array}$ \\
\hline $\begin{array}{l}\text { Sahar } \\
\text { Mansour, } \\
\text { BMBS FRCP }\end{array}$ & $\begin{array}{l}\text { Thames Regional } \\
\text { Genetics Service, St } \\
\text { George's University of } \\
\text { London, London, United } \\
\text { Kingdom }\end{array}$ & $\begin{array}{l}\text { Interpretation of genetic } \\
\text { results and revision of the } \\
\text { manuscript }\end{array}$ \\
\hline $\begin{array}{l}\text { Laszlo Sztriha, } \\
\text { MD PhD FRCP }\end{array}$ & $\begin{array}{l}\text { King's College Hospital, } \\
\text { London, United Kingdom }\end{array}$ & $\begin{array}{l}\text { Performed initial clinical } \\
\text { diagnosis, interpretation } \\
\text { of data, and revision of } \\
\text { the manuscript }\end{array}$ \\
\hline
\end{tabular}

\section{References}

1. Phowthongkum $\mathrm{P}$, Chen DH, Raskind WH, Bird T. SAMD9L-Related ataxiapancytopenia syndrome. In: Adam MP, Ardinger HH, Pagon RA, et al., eds. Gene Reviews $\left.{ }^{\circledast}\right)$ : University of Washington, Seattle Copyright (C) 1993-2020, University of Washington, Seattle. GeneReviews is a registered trademark of the University of Washington, Seattle. All rights reserved; 1993.

2. Chen DH, Below JE, Shimamura A, et al. Ataxia-pancytopenia syndrome is caused by missense mutations in SAMD9L. Am J Hum Genet 2016;98:1146-1158.

3. Gorcenco S, Komulainen-Ebrahim J, Nordborg K, et al. Ataxia-pancytopenia syndrome with SAMD9L mutations. Neurol Genet 2017;3:e183.

4. Tesi B, Davidsson J, Voss M, et al. Gain-of-function SAMD9L mutations cause a syndrome of cytopenia, immunodeficiency, MDS, and neurological symptoms. Blood 2017;129:2266-2279.

5. Stenson PD, Ball EV, Mort M, et al. Human gene mutation database (HGMD): 2003 update. Hum Mutat 2003;21:577-581.

6. Pastor VB, Sahoo SS, Boklan J, et al. Constitutional SAMD9L mutations cause familial myelodysplastic syndrome and transient monosomy 7. Haematologica 2018;103: 427-437.

7. Davidsson J, Puschmann A, Tedgård U, Bryder D, Nilsson L, Cammenga J. SAMD9 and SAMD9L in inherited predisposition to ataxia, pancytopenia, and myeloid malignancies. Leukemia 2018;32:1106-1115. 


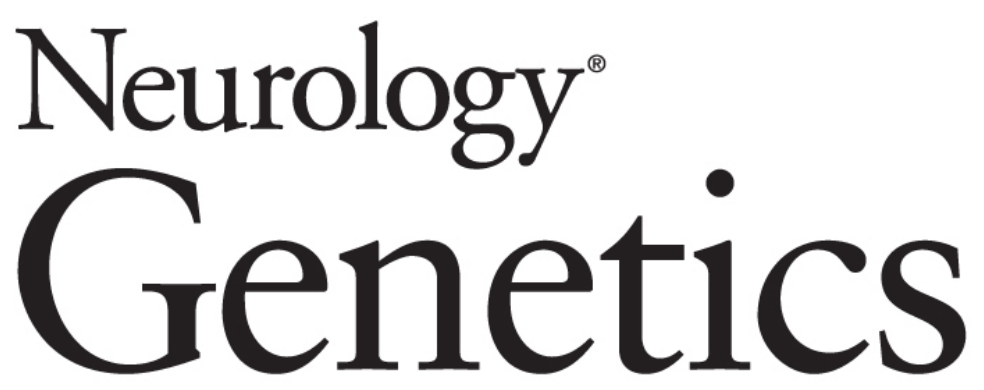
Ataxia-Pancytopenia Syndrome due to a de Novo SAMD9L Mutation Josh King-Robson, Joseph Marshall, Frances Smith, et al. Neurol Genet 2021;7;
DOI 10.1212/NXG.0000000000000580

This information is current as of March 24, 2021

Neurol Genet is an official journal of the American Academy of Neurology. Published since April 2015, it is an open-access, online-only, continuous publication journal. Copyright Copyright $\odot 2021$ The Author(s). Published by Wolters Kluwer Health, Inc. on behalf of the American Academy of Neurology.. All rights reserved. Online ISSN: 2376-7839.

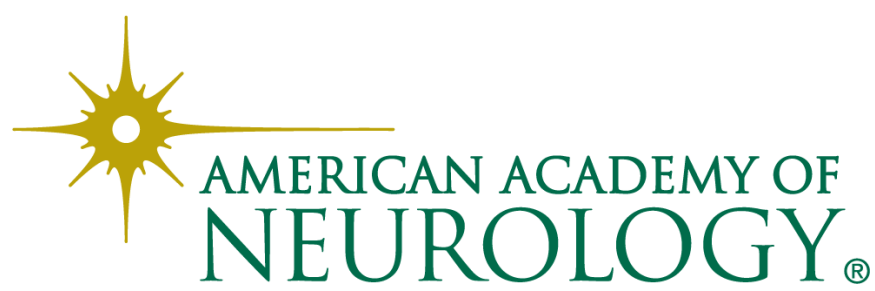




\section{Updated Information \& Services}

References

Citations

Subspecialty Collections

Permissions \& Licensing

Reprints including high resolution figures, can be found at: http://ng.neurology.org/content/7/3/e580.full.html

This article cites 6 articles, 3 of which you can access for free at: http://ng.neurology.org/content/7/3/e580.full.html\#\#ref-list-1

This article has been cited by 1 HighWire-hosted articles: http://ng.neurology.org/content/7/3/e580.full.html\#\#otherarticles

This article, along with others on similar topics, appears in the following collection(s):

\section{Cerebellum}

http://ng.neurology.org//cgi/collection/cerebellum

Diplopia (double vision)

http://ng.neurology.org//cgi/collection/diplopia_double_vision

Gait disorders/ataxia

http://ng.neurology.org//cgi/collection/gait_disorders_ataxia

Hematologic

http://ng.neurology.org//cgi/collection/hematologic

Nystagmus

http://ng.neurology.org//cgi/collection/nystagmus

Information about reproducing this article in parts (figures,tables) or in its entirety can be found online at:

http://ng.neurology.org/misc/about.xhtml\#permissions

Information about ordering reprints can be found online:

http://ng.neurology.org/misc/addir.xhtml\#reprintsus

Neurol Genet is an official journal of the American Academy of Neurology. Published since April 2015, it is an open-access, online-only, continuous publication journal. Copyright Copyright ( 2021 The Author(s). Published by Wolters Kluwer Health, Inc. on behalf of the American Academy of Neurology.. All rights reserved. Online ISSN: 2376-7839.

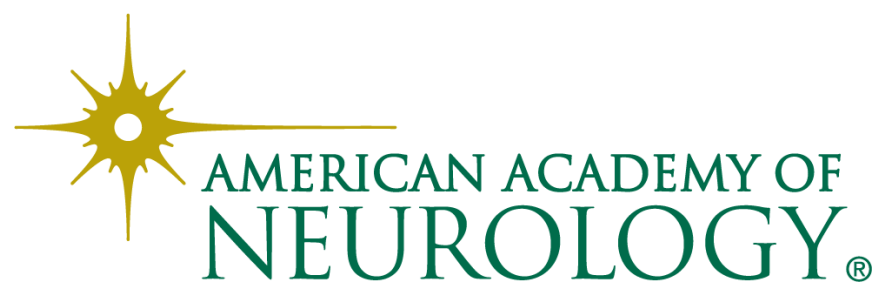

